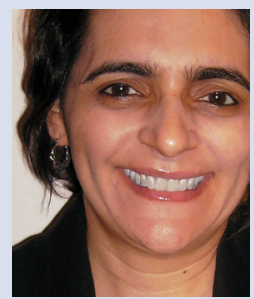

Isleide Arruda Fontenelle FGV-EAESP isleide.fontenelle@fgv.br

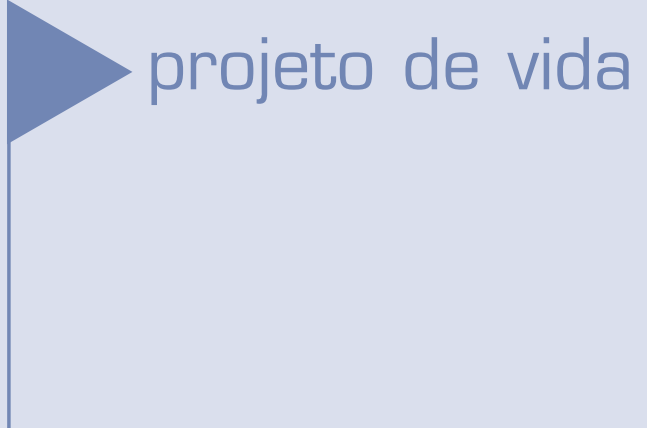

\title{
Felicidade e sofrimento
}

\section{EM SEU CÉLEBRE TEXTO O MAL-ESTAR NA CIVILIZAÇÃO. DE 1929. SIGMUND FREUD ALERTAVA QUE O TRABALHO NÃO PARECIA APRESENTAR A POSSIBILIDADE DE UM CAMINHO PARA A FELICIDADE}

Como ficou claro depois. Freud se referia a um tipo de trabalho específico, produto de uma sociedade peculiar: a moderna sociedade da ordem, da Revolução Industrial, do trabalho repetitivo e monótono.

Dessa perspectiva, o trabalho virou sinônimo de sofrimento, gerando uma infinidade de escritos posteriores que apontam para sua inadequação sempre que descolado de alguma forma de significado para aqueles que o realizam. Mesmo segundo o ponto de vista das práticas e discursos dos que tentaram conciliar trabalho e felicidade, como aquele iniciado ainda nos anos 1930 com o surgimento da "escola das relações humanas", também havia a idéia do sofrimento ou, pelo menos, de certa ausência de realização no trabalho.

Mas, quase 80 anos depois, será que as palavras de Freud ainda fazem sentido em meio a um cenário no qual impera um discurso em torno do trabalho criativo que. embora sem ser, por enquanto, o modelo hegemônico, já opera de uma forma imaginária como promessa de autonomia, autoafirmação, singularidade; enfim, de liberdade e, portanto, de felicidade?

Hoje, a tônica da relação entre felicidade e sofrimento no trabalho parece dirigir-se para outro tipo de sofrimento. Segundo o sociólogo Richard Sennett, em A cultura do novo capitalismo (2006), o ideal cultural necessário às novas instituições requer um tipo novo de trabalhador, apto a dar conta de três capacidades fundamentais: a do tempo - como cuidar de si mesmo e das relações de curto prazo em um contexto instável de emprego; a do talento - como se capacitar continuamente para dar conta das exigências da realidade em mutação; e a da descartabilidade - a capacidade de deixar para trás experiências já vividas, de esquecer o passado e buscar o novo continuamente. Trata-se de um modelo carregado de contradições e críticas, já que, conforme constatado por Sennett, causa sofrimento.

Outra compreensão desse cenário do trabalho é a do sociólogo Zygmunt Bauman, quando esse discute a tensão entre segurança e liberdade. Segundo Bauman, é praticamente impossível termos as duas coisas ao mesmo tempo. A época de Freud, retratada nas páginas do Mal-estar da civilização, era aquela que havia trocado parte de sua liberdade por segurança. A nossa optou por um quinhão maior de liberdade. Assim, qualquer que seja nossa escolha, ganhamos de um lado e perdemos de outro. O problema talvez esteja na aposta de que uma das escolhas haverá de nos proporcionar a felicidade idealizada. 